\title{
PENDIDIKAN ACARA AGAMA HINDU: Antara Tradisi dan Modernitas
}

\author{
Oleh: \\ Ni Made Sukrawati \\ Fakultas Pendidikan Agama dan Seni \\ Universitas Hindu Indonesia
}

\begin{abstract}
Acara is one part of three Hindu religious frameworks. It is the dimension of religious rituality. The combination of the religious texts with the local traditions gives a sense of traditionality in the practice of Hindu religious rituals. Conversely, the penetration of the modernity also brought changes in the mindset and religious actions of the Hindus. The education as a process of transmission and transformation of the Hindu religious values must be able to adapt both the traditional and the modern values. In this case, a transformational thinking approach that encompasses the behavioral system, a system of thinking, and a belief system can be applyed as the solution in designing the educational Hindu rituals, the so-called acara. Through this systemic approach, the education of Hindu religious rituals is expected to develop the students' morality, rationality and religiosity as a whole and integrated. This approach can be implemented through four stages of constructivist learning, namely schemata, assimilation, accommodation, and equilibration.
\end{abstract}

Keywords: education, events, tradition, modernity.

\begin{abstract}
Abstrak
Acara adalah bagian dari tiga kerangka agama Hindu, yaitu dimensi ritualitas keagamaan. Perpaduan teks agama dengan tradisi lokal memberikan nuansa tradisionalitas dalam praktik ritual keagamaan Hindu. Sebaliknya, penetrasi modernitas juga membawa perubahan pola pikir dan tindakan keagamaan umat Hindu. Pendidikan sebagai proses transmisi dan transformasi nilai-nilai acara agama Hindu harus mampu mengadaptasi nilai tradisional dan modern. Dalam hal ini, pendekatan transformational thinking yang mencakup sistem perilaku, sistem berpikir, dan sistem kepercayaan dapat dijadikan solusi dalam merancang pendidikan acara agama Hindu. Melalui pendekatan sistemik ini, pendidikan acara agama Hindu diharapkan dapat mengembangkan moralitas, rasionalitas, dan religiusitas peserta didik secara utuh dan terpadu. Pendekatan ini dapat dilaksanakan melalui empat tahap pembelajaran konstruktivistik, yakni skemata, asimilasi, akomodasi, dan ekuilibrasi.
\end{abstract}

Kata kunci: pendidikan, acara, tradisi, modernitas.

\section{PENDAHULUAN}

Agama Hindu dibangun oleh tiga kerangka, yaitu tattwa, susila, dan acara. Tattwa berarti hakikat kebenaran yang mutlak, susila berarti tingkah laku yang baik, dan acara berarti ritual keagamaan. Sudharta dan Punyatmaja (2001:5) mengibaratkan tattwa sebagai kepala, susila sebagai hati, dan acara sebagai tangan-kaki agama Hindu. Ketiga kerangka ini tidak dapat 
dipisahkan satu sama lain dan mendasari seluruh aspek pelaksanaan ajaran agama Hindu. Dalam keberagamaan umat Hindu di Bali, ketiga kerangka tersebut dipraktikkan di dalam dan melalui kebudayaan Bali. Dengan kata lain, kebudayaan Bali merupakan bagian integral pelaksanaan agama Hindu sehingga antara agama dan budaya Bali acapkali sulit dipisahkan (Wesnawa, 2004:12).

Walaupun demikian, ilmu pengetahuan dan tekhnologi secara signifikan telah mengubah pola pikir umat Hindu di Bali. Umat Hindu mulai bersikap kritis terhadap ajaran dan praktik keagamannya. Berbagai ritual keagamaan yang dulu diterima begitu saja (mula keto) secara turun-temurun (gugon tuhon), sekarang mulai dipertanyakan. Salah satu dalihnya bahwa agama yang hanya didasari mula keto dan gugon tuhon akan mudah goyah, bahkan runtuh saat berhadapan dengan pemikiran kritis (Tim Penyusun, 2009:5). Implikasinya bahwa kegairahan umat Hindu untuk menggali sumbersumber yang mendasari tradisi keagamaannya juga semakin meningkat. Dinamika ini menurut Triguna (dalam Pitana, (ed.), 1994:80), juga menandai terjadinya pergerakan pemikiran umat Hindu di Bali dari ritualisme ke tattwaisme. Artinya, umat Hindu menghendaki agar setiap ritual keagamaannya (ritualisme) didasari aturan-aturan dan filsafat agama (tattwaisme) yang jelas, pun baku.

Berbeda halnya dengan aspek tattwa dan susila yang dapat merujuk langsung pada teksteks suci Hindu, justru aspek acara sangat kental dengan tradisi lokal. Hal ini tentu memberikan tantangan tersendiri bagi pendidikan acara agama Hindu terutama dalam pergulatan nilai tradisional dan modern. Pada satu sisi, tradisi dan budaya lokal dalam praktik acara penting dipertahankan karena telah membentuk sistem nilai yang mendasari keberagamaan umat Hindu di Bali. Sebaliknya, juga pada sisi lain teori-teori modernisasi menegaskan bahwa nilai-nilai modern merupakan kekuatan yang dapat mengikis nilai-nilai tradisional, bahkan modernitas adalah kontras dari tradisionalitas (Suhandji dan Waspodo, 2004:19). Paradoks tersebut mengisyaratkan pentingnya suatu paradigma baru dalam penyelenggaraan pendidikan acara agama Hindu terutama untuk mengintegrasikan nilai tradisional dan modern.

Undang-undang Nomor 20 Tahun 2003 tentang Sistem Pendidikan Nasional, pasal 4 ayat (1) menyebutkan bahwa pendidikan diselenggarakan secara demokratis dan berkeadilan serta tidak diskriminatif dengan menjunjung tinggi hak asasi manusia, nilai keagamaan, nilai kultural, dan kemajemukan bangsa. Prinsip ini menegaskan bahwa setiap nilai kultural keagamaan adalah sumber pembelajaran untuk mewujudkan tujuan pendidikan secara keseluruhan. Berdasarkan prinsip tersebut, pendidikan acara agama Hindu perlu dirancang untuk mempertahankan nilainilai kultural yang inheren dengan tradisionalitas, juga sekaligus mengembangkan rasionalitas peserta didik yang sejalan dengan nilai-nilai modern. Salah satunya melalui pendekatan transformational thinking yang dipadukan dengan teori belajar konstruktivistik melalui empat tahap, yaitu skemata, asimilasi, akomodasi, dan ekuilibrasi. Dengan paradigma baru tersebut, pendidikan acara agama Hindu diharapkan dapat mengembangkan sistem perilaku, sistem berpikir, dan sistem kepercayaan peserta didik secara utuh dan menyeluruh. Inilah dimensi penting yang hendak dibahas dalam makalah ini.

\section{PEMBAHASAN}

\subsection{Ranah Pendidikan Acara Agama Hindu}

Kata acara (ācāra) menurut Sanskrit-English Dictionary (Moonier-Williems, 1872:131) antara lain diartikan: peraturan, tindakan, tingkah laku, perilaku yang baik, kebiasaan, praktik, dan aturan perilaku. Acara mengacu pada aturan perilaku dan adat kebiasaan (custom law) yang tumbuh dalam kehidupan masyarakat. Dalam sejumlah teks Hindu, acara merupakan salah satu sumber hukum Hindu seperti disebutkan dalam Manawa Dharmasastra Bab II sloka 6, berikut ini.

Idanim dharma pramananyaha, wedo'khilo dharma mulam,

smrtisile ca tadvidam,acarascaiwa sadhunam, atmanastutirewa ca.

Artinya:

Seluruh pustaka suci Weda adalah sumber pertama daripada dharma, lalu adat istiadat, dan tingkah laku terpuji dari orang-orang budiman yang mendalami ajaran pustaka suci Weda, 
juga tata cara perikehidupan orangorang suci, dan akhirnya kepuasan diri pribadi (Pudja dan Sudharta, 2002:62).

Dari sloka tersebut, kata acara mengacu pada adat-istiadat, kebiasaan, tradisi, dan tata cara kehidupan sebagai wujud penghayatan dan pengamalan ajaran suci Weda. Pengertian acara juga ditemukan dalam kitab Sarasamuccaya (177), sebagai berikut:

Nihan pajara mami, phala sang hyang weda inaji, kapujan sang hyang siwagni, rapwan wruhing mantra, yajnangga widdhiwaidhanadi, dening dana hinanaken, bhuktin danakena, yapwan dening anakbi, dadyaning alingganadi krida mahaputri-santana, kuneng phala sang hyang aji kinawruhan, haywaning gila ngaraning swabhawa, acara ngaraning prawrtti kawaran ring aji.

Artinya:

Inilah yang hendak hamba beritahukan, gunanya kitab suci Weda dipelajari, Siwagni patut dipuja, patut diketahui mantra serta bagian-bagian dari kurban persembahan, widhi-widhana, dan lainlain. Adapun gunanya harta kekayaan disediakan untuk dinikmati dan disedekahkan, akan guna wanita adalah untuk menjadi istri dan melanjutkan keturunan baik pria dan wanita, guna sastra suci adalah untuk diketahui dan diamalkan, acara adalah tindakan yang sesuai dengan ajaran agama.

Mengacu pada beberapa teks tersebut, maka acara berarti adat kebiasaan atau tindakan yang sesuai ajaran agama. Acara sebagai kebiasaan mendekati arti kata drsta yang berarti memandang atau melihat. Kemudian, kata $d r s t a$ memiliki makna konotatif sebagai tradisi (Sudharma, 2000). Drsta dibagi menjadi lima (panca drsta), yaitu: (1) sastra drsta, tradisi yang bersumber dari pustaka suci Hindu; (2) desa drsta, tradisi agama yang berlaku pada wilayah tertentu; (3) loka drsta, tradisi agama yang berlaku secara umum pada wilayah yang lebih luas; (4) kuna atau purwa drsta, tradisi agama yang berlaku secara turun-temurun dan diikuti terus-menerus sejak lama; dan (5) kula drsta, tradisi agama yang berlaku dalam keluarga (Subagiasta, dkk., 1996:8). Dengan demikian, acara mencakup keseluruhan praktik keagamaan, baik yang bersumber dari pustaka suci Weda maupun tradisi atau budaya lokal.

Secara umum, acara agama Hindu menampakkan diri dalam praktik ritual, baik upacara maupun upakara. Upacara berarti rangkaian tindakan dalam kegiatan ritual, sedangkan upakara berarti pelayanan yang ramah, dan sarana kebaktian (Sura, dkk., 2005:139-140). Acara sebagai sistem ritual keagamaan Hindu mengisyaratkan adanya sejumlah elemen di dalamnya, yaitu (a) konsep ritual yang terimplementasikan dalam ajaran panca yadnya; (b) aturan mengenai tempat dan waktu pelaksanaan ritual; (c) komponenkomponen dalam ritual, seperti pelaksana ritual dan sarana ritual; dan (d) budaya pendukung ritual. Elemen-elemen inilah yang kemudian dituangkan secara rinci dalam kurikulum pendidikan agama Hindu pada berbagai jenjang pendidikan, meliputi:

(1) Ajaran Panca Yadnya (Dewa, rshi, manusia, pitra, dan bhuta yadnya);

(2) Sistem Wariga (perhitungan baikburuknya hari/ala-ayuning dewasa);

(3) Hari-hari suci keagamaan Hindu;

(4) Tempat suci keagamaan Hindu;

(5) Orang-orang suci Hindu;

(6) Prosesi ritual keagamaan (upacara);

(7) Sarana upacara pemujaan dan persembahan (upakara);

(8) Senibudaya pendukung ritual keagamaan Hindu.

Pendidikan acara agama Hindu merupakan serangkaian aktivitas belajar dan pembelajaran untuk membangun pengetahuan, keterampilan, dan kesadaran peserta didik pada 8 (delapan) ranah tersebut. Pengetahuan acara harus diintegrasikan dengan pengetahuan tattwa dan susila sehingga terbentuk sistem pengetahuan secara utuh dan terpadu. Keterampilan dalam pelaksanaan ritual juga penting, mengingat acara agama Hindu merupakan ranah praksis keagamaan. Sementara itu, kesadaran yang penting dibangun adalah menginternalisasikan nilai-nilai acara agama Hindu sebagai pedoman dalam sikap dan perilaku keagamaan.

\subsection{Pendekatan} Thinking

Transformational thinking atau cara berpikir transformasional adalah suatu pendekatan yang 
bersumber dari perkembangan filsafat esoterik sekitar tahun 1850-an. Semula pendekatan ini hanya berkorelasi dengan hubungan alami antara manusia dan masyarakat, tetapi juga berangsur-angsur berkorelasi dengan transformasi dunia kerja, sekolah, dan pemerintahan (Izzan dan Artyasa, 2013:41). Pendekatan ini memandang bahwa terdapat keterkaitan yang erat antara sistem perilaku (behavior system), sistem berpikir (thinking system) dan sistem kepercayaan (believe system) (Gunawan, 2007: 15). Interaksi ketiga sistem tersebut dapat diringkas sebagai berikut.

Sistem perilaku (behavior system) adalah cara kita berinteraksi dengan dunia luar, juga interaksi dengan realitas sebagaimana kita memahami realitas itu. Perilaku kita memengaruhi pengalaman kita, dan juga sebaliknya. Pengalaman akan memengaruhi sistem berpikir. Sistem berpikir (thinking system) menjadi filter dua arah yang menerjemahkan berbagai kejadian dan pengalaman yang kita alami menjadi suatu kepercayaan. Selanjutnya, kepercayaan ini akan memengaruhi tindakan kita, sehingga menciptakan realitas bagi diri kita. Dengan mempelajari keterampilan berpikir yang baru, kita dapat mengubah sistem kepercayaan dan sistem perilaku kita. Sistem kepercayaan (believe system) adalah inti dari segala sesuatu yang kita yakini sebagai realitas, kebenaran, nilai hidup, dan segala sesuatu yang kita tahu mengenai dunia ini (Gunawan, 2007:16).

Sistem perilaku merupakan lapisan terluar, yakni cara seseorang berinteraksi dengan dunia atau realitas yang dihadapinya. Sistem perilaku ini hendaknya dipandang sebagai perilaku sadar, yakni perilaku yang didasari oleh cara berpikir dan kepercayaan seseorang. Sistem perilaku ini dapat berubah seiring perubahan kesadaran seseorang, yakni perubahan cara berpikir dan kepercayaannya. Perubahan itu terjadi melalui cara seseorang menerjemahkan dan memaknai pengalaman yang dicerap dalam kehidupan sehari-hari. Pengalaman inilah yang memengaruhi cara berpikir seseorang, dan dengan keterampilan berpikir baru sistem kepercayaan dan sistem perilakunya dapat berubah. Membangun keterampilan berpikir baru inilah penekanan utama dalam pendekatan transformational thinking.

Berpikir transformasional didasari asumsi bahwa "kita harus memengaruhi perubahan yang ada, bukan terpengaruh oleh perubahan yang terjadi". Oleh karena itu, diperlukan latihan dan bimbingan secara berkelanjutan untuk melewati fase transisi dari cara berpikir tradisional (traditional thinking) menuju ke cara berpikir transformatif (transformational thinking) (Izzan dan Artyasa, 2013:41-42). Berkenaan dengan itu, Gould (2006:17-18) membagi ide utamanya menjadi "11P", sebagai berikut.

"Peningkatan parameter persepsi (perception) menuntun ke arah pemahaman potensi (potential) penuh diri sendiri dan kolektif. Ketika potensi digabungkan dengan prinsip (principle) dan gairah (passion), kita menciptakan definisi keyakinan kita dan dapat mencurahkan diri untuk memeliharanya. Ketika kita memahami politik (politics) hubungan dan orang (people) lain diikutsertakan serta terlibat dalam masalah yang memengaruhi mereka, kita memiliki sasaran sama yang akan menentukan tujuan (purpose) dan semua orang berpegang teguh padanya. Kemudian, kita dapat merumuskan rencana (plan) yang akan membawa kita pada penciptaan proses (process) yang membantu mencapai sasaran kita. Unsur akhirnya adalah ketabahan (perseverance) dan keluwesan (pliability). Keduanya memberikan keluwesan dan kekuatan yang diperlukan untuk menjamin pertumbuhan serta perbaikan yang berkesinambungan".

Jadi, cara kerja transformational thinking adalah bagaimana mengembangkan parameter persepsi seseorang agar memahami sepenuhnya potensi dirinya, baik sebagai makhluk individu maupun sosial. Potensi yang dipadukan dengan prinsip dan gairah membangun kepercayaan seseorang. Selanjutnya, seseorang dapat mengelola politik hubungan untuk mempengaruhi orang lain agar memiliki masalah yang sama, dan dengan demikian dapat diarahkan untuk mewujudkan sasaran dan tujuan bersama. Dari sini kemudian, dapat disusun sebuah rencana yang membawa pada sebuah proses kerja. Agar proses ini menghasilkan pertumbuhan dan perbaikan 
yang berkelanjutan, maka diperlukan keuletan dan keluwesan dalam menjaga terpeliharanya proses sampai tujuan bersama benar-benar terwujud.

Dalam konteks pendidikan acara agama Hindu, pendekatan transformational thinking dapat dikembangkan terutama dalam fase transisi perubahan dari masyarakat tradisional ke modern. Tujuannya agar umat Hindu dapat memengaruhi perubahan yang terjadi, bukan malah sebaliknya terpengaruh dalam perubahan tersebut. Dalam hal ini, tenaga pendidik harus mampu mengubah cara berpikirnya sendiri dan cara berpikir para peserta didik tentang acara agama Hindu. Caranya dengan mengikuti konsep "11 P" di atas, yakni (1) mengembangkan cakrawala persepsi; (2) mengenali potensi diri; (3) memadukan potensi dengan prinsip dan (4) gairah; (5) mengelola politik interaksi; (6) memengaruhi orang lain agar merasa memiliki masalah yang sama; (7) menetapkan sasaran dan tujuan bersama; (8) merumuskan rencana; (9) melaksanakan proses; (10) keuletan dan ketabahan; serta (11) keluwesan. Kesebelas aspek ini dapat dikembangkan dalam pembelajaran acara agama Hindu dalam rangka membangun sistem perilaku, sistem berpikir, dan sistem kepercayaan peserta didik.

\subsection{Empat Tahap Pembelajaran Konstruktivistik}

Pendekatan transformational thinking mengisyaratkan pentingnya perubahan sistem berpikir (thinking system) yang akan memengaruhi sistem perilaku (behavior system) dan sistem kepercayaan (believe system) seseorang. Perubahan ini dapat terjadi ketika seseorang dapat menerjemahkan pengalaman yang diperoleh dalam interaksinya dengan lingkungan sehingga menjadi pengetahuan baru yang bermakna bagi dirinya sendiri. Dalam hal ini, fungsi utama pendidikan adalah mengarahkan peserta didik agar mampu mengkonstruksi pengetahuannya sendiri dan mengoptimalkan segenap potensi yang dimiliki. Artinya, pendekatan transformational thinking sejalan dengan asumsi dasar teori pembelajaran kontsruktivistik sehingga keduanya niscaya dipadukan.

Dalam pandangan konstruktivistik, peserta didik harus dillihat sebagai subjek yang telah memiliki persepsi (perception), potensi (potential), prinsip (principle), dan gairah (passion) dalam dirinya. Tugas utama seorang pendidik adalah mengoptimalkan dan mengembangkan keempat aspek tersebut dengan cara mengintegrasikan berbagai informasi baru dalam struktur pengetahuannya. Untuk itu, diperlukan strategi (politics) interaksi dengan peserta didik (peoples) sehingga kelas dapat bertransformasi menjadi arena pembelajaran yang produktif. Selanjutnya, tugas pendidik adalah merencanakan (plan) pembelajaran, menetapkan tujuan (purpose) pembelajaran, serta melaksanakan proses (process) pembelajaran sesuai rencana dan mengarah pada tujuan yang hendak dicapai. Pada akhirnya, integritas pendidik dalam bentuk keuletan (preserverance) dan keluwesan (pliability) menjadi kunci dalam mengelola seluruh proses tersebut.

Berkenaan dengan itu, Budiningsih (2005:23) menegaskan bahwa teoribelajarkonstruktivistik berpijak pada landasan berpikir kontekstual, yaitu pengetahuan yang dibangun sedikit demi sedikit, dan hasilnya diperluas melalui konteks yang terbatas dan tiba-tiba. Proses konstruksi pengetahuan dapat berlangsung melalui empat tahapan, yakni ; Skemata, asimilasi, akomodasi, dan ekuilibrasi, sebagaimana penjelasan berikut.

Proses skemata adalah suatu proses yang dilakukan dengan cara mengulang -ulang suatu kegiatan dengan bentuk yang sama sehingga kegiatan ini yang menjembatani antara pengalaman dengan struktur kognitif individu. Proses asimilasi adalah proses pengintegrasian atau penyatuan informasi baru ke dalam struktur kognitif yang telah dimiliki oleh individu. Proses akomodasi adalah proses penyesuaian struktur kognitif ke dalam situasi yang baru. Proses ekuilibrasi adalah penyesuaian secara berkesinambungan antara asimilasi dan akomodasi. Agar supaya seseorang dapat menambah dan mengembangkan pengetahuannya secara terus-menerus dan menjaga stabilitas mentalnya, maka diperlukan proses penyeimbangan antara lingkungan luar dengan struktur kognitif yang ada dalam dirinya. Proses inilah yang disebut ekuilibrasi (Peaget dalam Budiningsih, 2005:12-20).

Mengikuti pola pendekatan transformational thinking dan teori pembelajaran konstruktivistik tersebut, pendidikan acara agama Hindu dalam 
pergulatan tradisional dan modernitas dapat dikembangkan sebagai berikut.

Pertama, Skemata pengetahuan melalui pengintegrasian konsep-konsep acara sudah tertanam pada kognitif peserta didik karena suatu pengulangan kegiatan yang sama yang dilakukan berulang-ulang masih tertanam pada kognitif individu. Seperti halnya tentang ritual keagamaan hindu, persembahyangan, konsepkonsep tersebut dapat menjembatani unsur kognitif dengan pengalaman yang di alami oleh peserta didik.

Kedua, asimilasi pengetahuan melalui pengintegrasian konsep-konsep acara agama Hindu, seperti panca yadnya, wariga, hari suci, tempat suci, orang-orang suci, proses ritual, sarana dan prasarana ritual, serta budaya keagamaan lainnya ke dalam struktur kognitif peserta didik. Penguatan konsep-konsep tersebut diharapkan dapat menjembatani kesenjangan antara nilai tradisional dan modern dalam pendidikan acara agama Hindu. Pada satu sisi, penguatan konseptual dapat memberi penjelasan rasional atas berbagai praktik acara agama Hindu sebagaimana tuntutan masyarakat modern. Sebaliknya, penguatan konsep ini juga dapat mengubah sistem berpikir tradisional yang cenderung mula keto dan gugon tuhon. Dengan demikian, penjelasan rasional (tekstual) yang dapat mencerahi praktik acara agama Hindu (kontekstual) harus dijadikan sebagai sistem berpikir baru dalam pendidikan acara agama Hindu.

Ketiga, proses akomodasi pengetahuan adalah penyesuaian struktur kognitif dalam situasi baru. Proses ini mengisyaratkan pentingnya memberikan bimbingan dan latihan kepada peserta didik tentang cara melakukan praktik acara agama Hindu secara nyata. Melibatkan peserta didik dalam pelaksanaan acara agama Hindu dapat dijadikan upaya pembelajaran secara terpadu. Dengan menghadapkan peserta didik pada situasi nyata akan terjadi transformasi belajar dari learn to know ('belajar untuk mengetahui') menjadi learn to do ('belajar melakukan'). Apalagi acara agama Hindu merupakan dimensi praksis keagamaan sehingga kemampuan untuk melakukan lebih dipentingkan, daripada sekadar mengetahuinya. Pembentukan keterampilan teknis dalam acara juga harus dijadikan sistem berpikir berikutnya dalam pendidikan acara agama Hindu.

Keempat, proses ekuilibrasi berkaitan dengan penyeimbangan antara asimilasi dan akomodasi secara berkesinambungan sehingga peserta didik dapat menambah dan mengembangkan pengetahuannya, serta menjaga stabilitas mentalnya. Proses ini dapat dilakukan dengan mengembangkan daya kritis peserta didik atas fenomena keagamaan Hindu di lingkungan sekitarnya. Pemahaman menengai perubahan praktik keagamaan Hindu yang cenderung disemangati oleh modernitas, seperti munculnya pasar ritual, diferensiasi struktur keagamaan, teknologisasi sarana dan prasarana keagamaan perlu dikenalkan, tetapi perlu disertai penjelasan implikasi postitif dan negatifnya. Dengan demikian, peserta didik dapat memosisikan diri dalam perubahan, baik sebagai upaya menemukan jati diri (learn to be) maupun memahami realitas sosial sebagai langkah pembelajaran untuk hidup bersama (living together) dalam masyarakat.

Keempat tahapan tersebut harus berjalan secara simultan sehingga pengetahuan peserta didik tidak berjarak dengan realitas yang dihadapi. Sejalan dengan pendekatan transformational thinking, pendidikan acara agama Hindu harus mampu membangun sistem perilaku (behavior system) peserta didik, yakni kemampuan memahami realitas acara agama Hindu secara utuh dan menjadikannya panduan perilaku. Sistem perilaku ini akan terpelihara dan berkembang secara berkesinambungan apabila peserta didik mampu mengubah sistem berpikirnya (thinking system) dengan memaknai pengalaman tentang acara agama Hindu pada ranah praksis. Artinya, praktik acara yang terjadi saat ini harus dipahami sebagai realitas yang niscaya, walaupun mungkin telah berubah dari tatanan tradisi sebelumnya. Sistem berpikir yang mampu menyikapi terjadi perubahan inilah hakikat berpikir transformasi. Pada akhirnya, sistem perilaku dan berpikir ini harus didasari sistem kepercayaan (believe system) sekaligus membangun kepercayaan itu sendiri bahwa acara agama Hindu merupakan nilai hidup, kebenaran, dan realitas yang wajib dijalani umat Hindu. 


\section{PENUTUP}

Pendidikan acara agama Hindu dalam tradisi dan modernitas merefleksikan sebuah tantangan pendidikan yang harus dijawab. Pada satu sisi, acara agama Hindu dengan kultur tradisionalnya telah menjadi sistem perilaku, sistem berpikir, dan sistem kepercayaan umat Hindu. Sebaliknya, modernitas menawarkan berbagai tata nilai baru yang meniscayakan terjadinya perubahan pada ketiga sistem tradisional tersebut. Oleh karena itu, pendidikan acara agama Hindu harus dirancang untuk mentransformasikan cara berpikir tradisional dengan mengasimilasi, mengakomodasi, dan mengekuilibrasi tata nilai modern menjadi sistem berpikir baru dalam memahami acara agama Hindu. Dalam hal ini, pendekatan transformational thinking dan teori belajar konstruktivistik dapat diterapkan secara terpadu serta berkesinambungan dalam ranah pendidikan acara agama Hindu dengan bertumpu pada rasionalitas, moralitas, dan spiritualitas. Dengan demikian, pendidikan acara agama Hindu dapat mentransformasi perubahan menjadi kekuatan untuk memantapkan sraddha dan bhakti umat Hindu dalam realitas kekinian. Gagasan transformational thinking pada puncaknya menghendaki terjadinya sebuah transformasi pemikiran setiap elemen masyarakat termasuk umat beragama, sehingga dapat menggerakkan transformasi sosiokultural yang memberikan manfaat yang lebih besar bagi kehidupan dan peradaban.

\section{DAFTAR PUSTAKA}

Budiningsih, C Asri. 2005. Pembelajaran Moral, Berpijak Pada Karakteristik Siswa dan Budayanya. Jakarta: PT Rineka Cipta.

Gould, Bil. 2006. Transformational Thinking: Champions of Change. Jakarta: Gramedia Pustaka Utama.

Gunawan, Adi W. 2007. The Secret of Mindset. Jakarta: Gramedia Pustaka Utama.

Izzan, Ahmad dan Ussin S. Artyasa. 2013. The Life Management: Menata Kelola Hidup Agar Lebih Bermakna dan Berbahagia. Bandung: Tafakur (kelompok HUMANIORA).

Puja, G dan Rai Sudharta, Tjokorda. 2004. Manawa Dharmacastra (Manu Smerti) Kompedium Hukum Hindu. Surabaya: Paramita.

Subagiasta, I Ketut. dkk. 1996. Acara Agama Hindu. Direktorat Jendral Bimbingan Masyarakat Hindu dan Budha.

Sudharta, Tjok Rai, dan Atmaja, Ida Bagus Oka Punia. 2001. Upadesa Tentang Ajaran-Ajaran Agama Hindu. Surabaya: Paramita.

Suhandji dan Waspodo TS. 2004. Modernisasi dan Globalisasi: Studi Pembangunan dalam Perspektif Global. Malang: Insan Cendekia.

Tim Penyusun. 2009. Dasar-dasar Penyuluhan Agama Hindu. Jakarta: Direktorat Jenderal Bimbingan Masyarakat Hindu Departemen Agama RI.

Triguna, I.B.G. Yudha. 1994. "Pergeseran dalam Pelaksanaan Agama: Menuju Tattwa" dalam Dinamika Masyarakat dan Kebudayaan Bali. (Pitana, I Gde (ed.) Denpasar: BP.

Undang-undang Nomor 20 Tahun 2003 tentang Sistem Pendidikan Nasional.

Wesnawa, Ida Bagus Putu. 2004. Revitalisasi Kebudayaan Bali. Denpasar: DPRD Provinsi Bali. 